\title{
A Review of Solar PV-Grid Energy Cost Parity in Akure, South-West Nigeria
}

\author{
Melodi A.O., Famakin S.R \\ Department of Electrical and Electronics Engineering, Federal University of Technology, Akure, Nigeria
}

\begin{tabular}{l}
\hline \hline Article Info \\
\hline Article history: \\
Received Feb 13, 2015 \\
Revised Jun 9, 2015 \\
Accepted Jun 24, 2015 \\
\hline
\end{tabular}

\section{Keyword:}

Electricity policy

Grid parity

PV-grid

Solar cell degradation

Solar energy

\begin{abstract}
The abundance of solar energy in Akure, South-West Nigeria and its feasibility as an alternative energy source has been proven. However, cheap, Government subsidized but unreliable grid electricity and high cost of solar equipment are considered the major hindrances to deployment of solar energy for improved power supply and environmental sustainability. An earlier work pointed out realistic pricing of electricity, reduced cost of solar equipment and reduction in solar cell degradation factor as major factors capable of speeding up parity hence, motivating solar energy consumption. It showed that parity is attainable within 14 years. Documented significant improvements in these factors in recent times are the motivations for this review. This review cost-comparatively re-assesses both sources of energy under the prevailing National electricity policy and market realities using simple mathematical and graphical modeling techniques. This is with a view to determining a new timing for parity of solar energy with grid supply. Results showed that solar PV-grid energy cost parity is now attainable within 6 years in the study region. It was also observed that sustained improvement in grid energy unit cost and reduction in cost of solar equipment and accessories may accelerate solar-grid energy parity to less than three years.
\end{abstract}

Copyright (C) 2015 Institute of Advanced Engineering and Science. All rights reserved.

\section{Corresponding Author:}

Melodi, A.O.

Department of Electrical and Electronics Engineering,

Federal University of Technology,

PMB 704, Akure, Nigeria.

e-mail: melodiadegoke@yahoo.com

\section{INTRODUCTION}

Inadequate and unreliable power supply has been a very significant constraint to socio-economic development in Nigeria. Generous government subsidy on the inadequate available power has been one of the major problems militating against the development and deployment of unconventional energy resources such as solar energy. Though solar energy is abundantly available in Akure $\left(+7^{\circ} 15^{\prime} \mathrm{N},+5^{\circ} 11^{\prime} 24^{\prime \prime}\right.$ E) and may be easily deployed to meet daily simple energy needs in areas such as transportation, recreation, domestic and industrial lighting and heating, mobile charging etc [1], the equipment and accessories for harnessing it are quite expensive. The recent privatization of the Nigerian power sector has led to systematic increase in the unit cost of electricity, which was a major incentive to early solar PV-Grid energy cost parity. The concept of parity is a major selling-point for renewable energy sources such as solar whose initial costs of procurement are often prohibitivecompared to traditional energy sources, though considered cheaper on the long run on account of little or no operational cost. As cheap energy is naturally attractive to consumers, it is important to assess the progress made by solar energy in approaching parity with grid supplied energy since [2]; this is the objective of this review.

The aim of this work is to assess the progress made towards grid parity between 2011 and 2014. In an earlier assessment by [2], the timing of parity for an installation carried out in that year was found to be $14.3 y e a r s$ or $57 \%$ of the useful life of a solar module. This review becomes necessary in view of the rapid 
changes in the following indices earlier identified in [2] as key to achieving early solar-grid electricity parity in the study location:

(i) Rapidly falling price/watt of solar modules, inverters and other accessories

(ii) Upward review of electricity tariff in Nigeria

(iii) New information and data on solar cell degradation in literature

Between 2011 and 2014 the average price of solar modules has reduced from \$4.18 to \$0.66 per watt [3] [4], the Multi-Year (electricity) Tariff Order (MYTO) introduced by the Nigerian Electricity Regulation Commission (NERC), in 2008, which was designed to establish a cost-reflective electric energy pricing within five years; i.e. 2008-2012 has experienced two reviews giving birth to the MYTO 2 (20122018) and MYTO 2.1 (2015-2018) respectively [5] [6] [7]. Each version of the policy portrayed varying but progressive upward review of the electricity tariffs across all sectors of Nigeria's socio-economy. In addition, [8] had proposed $0.71 \%$ annual solar cell degradation for crystalline silicon modules. However, emerging results from field tests on solar modules spanning over forty years carried out by the National Renewable Energy Laboratory (NREL) and covering a wide range of module technologies has put the figure averagely at $0.8 \%$ per annum and are now available in literature [9]. Consequent upon the foregoing, it is opined that the above combination of factors would have significantly affected earlier results obtained. Hence, there is need to investigate the new solar PV-grid energy cost parity scenario.

\section{RESEARCH METHODOLOGY}

\subsection{Energy and Power Demand Estimation}

Adopting a typical three room apartment in the study area, a demand estimate is carried out from first principles based on common and regular home appliances. The power ratings of each were determined from the ratings of similar commonly available appliances in the open market. Table 1 shows the details of compiled and applied demand assessment data.

Expected daily household energy consumption $\left(E_{H}\right)$ is obtained with consideration for diversity as in Equation 1:

$$
E_{H}=\sum_{i} E_{A(i)} ; E_{A(i)}=P_{A(i)} q_{A(i)} T_{A(i)}
$$

where $E_{A(i)}, P_{A(i)}, q_{A(i)}, T_{A(i)}$ represent energy consumption, unit appliance rating, quantity, and daily hours of use for $i^{\text {th }}$ appliance respectively.

Household peak load $\left(P_{H . p}\right)$ is obtained with consideration for divesity as in Equation 2, assuming power factor of unity:

$$
P_{H . p}=\sum_{i} d_{i} P_{A(i)} q_{A(i)}=d_{E Q} P_{H . T} ; P_{H . T}=\sum_{i} P_{A(i)} q_{A(i)} ;
$$

where $d_{i}$ is load diversification factor of $i^{\text {th }}$ appliance $[14,15]$, and $P_{H . T}$ istotal household connected load. From table 1 obtained $P_{H . p}$ is approximately 3,335 W.

However, average household load:

$$
P_{H . a v}=\frac{E_{H}}{24}=314.84 \mathrm{~W}
$$


Table 1. Compiled Demand Assessment Data and Estimation for a typical Household in Region

\begin{tabular}{|c|c|c|c|c|c|c|c|c|c|}
\hline$i$ & $\mathbf{A}$ & $P_{A(i)}, W$ & $q_{A(i)}$ & $P_{A(i)} q_{A(i)}, W$ & $T_{A(i)}, h r$ & $E_{A(i)}, W . h r$ & $P_{A V}, W$ & $d$ & $d_{i} P_{A(i)} q_{A(i)}, W$ \\
\hline 1 & CFL lamps & 15 & 14 & 210 & 12 & 2,520 & & 0.66 & 139 \\
\hline 2 & Television & 100 & 1 & 100 & 5 & 500 & & 0.4 & 40 \\
\hline 3 & Cable TV decoder & 10 & 1 & 10 & 3 & 30 & & 0.4 & 4 \\
\hline 4 & DVD player & 10 & 1 & 10 & 2 & 20 & & 0.4 & 4 \\
\hline 5 & Computer & 80 & 2 & 160 & 3 & 480 & & 0.4 & 64 \\
\hline 6 & Fan & 80 & 3 & 240 & 5 & 1,200 & & 0.4 & 96 \\
\hline 7 & Freezer & 160 & 1 & 160 & 12 & 1,920 & & 0.4 & 64 \\
\hline 8 & Blender & 250 & 1 & 250 & 0.1 & 25 & & 0.4 & 100 \\
\hline 9 & Wash Machine & 300 & 1 & 300 & 0.71 & 213 & & 0.4 & 120 \\
\hline 10 & Pressing Iron & 1000 & 1 & 1000 & 0.24 & 240 & & 0.4 & 400 \\
\hline 11 & Water Pump & 750 & 1 & 750 & 0.32 & 240 & & 0.4 & 300 \\
\hline 12 & Hair clipper & 10 & 1 & 10 & 0.03 & 0.3 & & 0.4 & 4 \\
\hline 13 & Mobile Phones & 0.15 & 4 & 0.6 & 2 & 1.2 & & 0.4 & 0 \\
\hline \multirow[t]{2}{*}{14} & Electric kettle & 2000 & 1 & 2000 & 0.083 & 166.67 & & 1 & 2,000 \\
\hline & & & & $3,200.6$ & & 7556.17 & 314.84 & 0.46 & $3,334.84$ \\
\hline
\end{tabular}

\subsection{Estimation of Deep Cycle Battery Capacity Needed}

At sun-up, the load is served from the solar modules via the inverter. If inverter output terminal voltage $V_{\text {inv.ac.o }}$ is regulated to $220 \mathrm{~V}$, then, average AC drawn by load in a day is given by:

$$
I_{\text {load.av }}=\frac{P_{\text {H.av }}}{V_{\text {inv.ac.o }}}=1.43 \mathrm{~A}
$$

At sun-down or during heavy cloud covering, the battery supplies $I_{\text {load.av }}=1.43$ Athrough the DCAC converter. If battery terminal voltage $V_{b a t . d c}$ is selected to be $24 \mathrm{~V}$, therelationship between the AC/DC quantities may be stated as:

$$
I_{\text {load.av }} V_{\text {inv.ac.o }}=I_{\text {bat.dc }} V_{\text {bat.dc }}
$$

Consequently, average battery current drawn by load in a day:

$$
I_{\text {bat.dc.av }}=\frac{I_{\text {load.av }} V_{\text {inv.ac.o }}}{V_{\text {bat.dc }}}=13.11 \mathrm{~A}
$$

If sun-up hourst $t_{u}=5.21$ hours [1], then sun-down hours $t_{d}$ is given by:

$$
t_{d}=24-t_{u}
$$

Minimum battery capacity $C_{\text {bat.min }}$ needed to cover this period is given by:

$$
C_{\text {bat }, \min }=\frac{t_{d} I_{\text {bat.dc.av }}}{\eta_{\text {bat. }}}=289.99 \mathrm{AH}
$$

where $\eta_{\text {bat. }}$ is battery efficiency. $\eta_{\text {bat. }}$ is valued at $85 \%$ (For deep cycle batteries, average $\eta_{\text {bat. }}$ varies from 80-90\%).

A standard overall battery capacity of 300AH is adequate for this application.

\subsection{Estimation of Solar Array Capacity}

Within the sun-up hours of 5.21hours, it is required that the battery be charged up. For the battery to charge up in charging time $t_{c}$ of 5hours, then, charging current $I_{c . d c}$ is given by:

$$
I_{c . d c}=\frac{C_{\text {bat.min }}}{t_{c}}=60 \mathrm{~A}(\mathrm{~A})
$$

Applyinganalogy in Equation 5, 


$$
I_{c . a c}=\frac{V_{b a t . d c} I_{c . d c}}{V_{a c}}=6.55 \mathrm{~A}
$$

Overall equivalent ac current drawn from the solar array is:

$$
I_{\text {inv.ac }}=I_{\text {c.ac }}+I_{\text {load.av }}=7.98 \mathrm{~A}
$$

Hence, total power drawn by battery and load through inverter is:

$$
P_{\text {inv }}=V_{\text {inv.ac.o }} I_{\text {inv.ac }}=1,755.60 \mathrm{~W}
$$

Average efficiency of domestic inverters is 95\% [10]; hence, Power delivered by solar array is given by:

$$
P_{p v}=\frac{P_{i n v}}{\eta_{i n v}}=1,848 \mathrm{~W}
$$

A system of $8 \times 250 \mathrm{~W}$ solar modules amounting to $2000 \mathrm{~W}$ solar array capacity may be adopted for the application.

\subsection{Inverter Capacity Estimation}

For any solar-electric power application designed to power $i$ appliances, if individual appliance power rating is $P_{A(i)}(\mathrm{KW})$, total connected load is denoted by $P_{H . T},(\mathrm{KW}), P_{\text {inv.rat. }}$ is inverter rating $(\mathrm{KW})$, then the capacity of inverter needed for any application should satisfy the condition:

$$
P_{\text {inv.rat. }} \geq P_{H . P .}
$$

From Equation 13, considering peak load and starting current effect of motorized appliances, 3500W inverter capacity is selected, which could have a peak capacity of up to $4000 \mathrm{~W}$.

\subsection{Utility Grid per Unit Energy Cost}

Energy billing history for residential load category (R2) from 2000-2007, were obtained from the system's energy and billing records, Akure, Nigeria.Also, the stipulations of energy cost for the same consumer category, spanning ten years (2008-2018), were extracted from the NERC's MYTO documents. With these two sets of data, an eighteen year energy cost trend spanning 2000 to 2018 was obtained. This cost variable is denoted $C_{g(n)}, n$ being year index.

\subsection{Solar PV Energy Cost Per Unit}

(i) Equipment Costing

Table 2 shows, the current cost of solar power equipment as obtained from ebay on-line store as of Januar2015. This has been used as the basis for the costing in Table 3. Total cost of solar PV system (annotated as $C_{T}$ ) is evaluated as in Equation 14.

$$
C_{T}=C_{P V}+C_{i n v .}+C_{\text {bat }}+C_{\text {struc. }}+C_{c a b}+C_{\text {Lab. }}
$$

where $C_{P V}, C_{i n v}, C_{\text {bat. }}, C_{\text {struc. }}, C_{c a b}$, and $C_{\text {Lab. }}$ are costs of solar panels, cost of inverter, cost of battery, cost of supporting steel structure, cost of cabling and terminations, and cost of labour respectively. Obtained values for these cost components and entire system are as shown in Table 3.

Table 2. Solar Equipment Price Index - January 2015 [17]

\begin{tabular}{llll}
\hline SN & Equipment & Average Price/unit (USD) & Sampled Manufacturers. \\
\hline 1 & 250W Solar & 230/Module & Unisolar, Sunware, Sanyosolar, Sharp Corporation, Suntech Power \\
& Module modules & & \\
2. & 3000W Inverter & 800/Unit & Solarix, Soltek, Powersine, Sharp, Electronics, Powerpro \\
3. & $\begin{array}{l}\text { Deep Cycle } \\
\text { Battery }\end{array}$ & 1.88/Amp-hour & Varta AG, Exide, Optima, Dyno,Trojan Battery, Deka \\
& & \\
\hline
\end{tabular}


Table 3. Bill of Estimate for the Installation of 2.0KW Solar PV System

\begin{tabular}{|c|c|c|c|c|c|c|}
\hline S/No & Solar PV System units & Unit & $\begin{array}{l}\text { Quantity/ } \\
\text { Capacity }\end{array}$ & Rate (\$) & $\begin{array}{l}\text { Costs } \\
\text { Notations }\end{array}$ & Cost (\$) \\
\hline 1 & 250W, 12/24V Crystalline Silicon Solar module & No & 8 & 230 & $C_{P V}$ & $1,840.00$ \\
\hline 2 & Inverter capacity & $\mathrm{W}$ & 3500 & 0.26 & $C_{\text {inv. }}$ & 910.00 \\
\hline 3 & Deep Cycle Battery & $\mathrm{AH}$ & 300 & 1.88 & $C_{\text {bat }}$ & 564.00 \\
\hline 4 & Solar modules' supporting steel structure & Lot & 1 & 100 & $C_{\text {struc. }}$ & 100.00 \\
\hline 5 & Cabling and terminations & Lot & 1 & 150 & $C_{c a b}$ & 150.00 \\
\hline 6 & Labour & Lot & 1 & 150 & $C_{L a b .}$ & 150.00 \\
\hline & $\begin{array}{c}\text { TOTAL } \\
\text { At NGN168/1.0USD exchange rate }\end{array}$ & & & & $C_{T}$ & $\begin{array}{l}\$ 3,714 \\
N 623,952\end{array}$ \\
\hline
\end{tabular}

Source of Exchange Rate: [18]

(ii) Estimation of Annual Energy production

Annual energy produced by the system is given by:

$$
E_{\text {ann }}=365 P_{p v} t_{u}=3,803.30 \mathrm{kWh}
$$

This represents original or nominal Energy Generation Capacity (EGC) of the solar module in the installation year.

\subsection{Mathematical Model for the Cumulative Energy Produced in the Installation's $\mathbf{n}^{\text {th }}$ Year}

Due to the phenomenon of cell degradation, the efficiency of solar modules drops with age. According to [9], the mean degradation rate of solar modules is $0 \cdot 8 \%$ per year. For an installation effected in 2015, if the overall electrical energy produced that year is denoted by $E_{n-1}(\mathrm{kWh})$, where $n$ indicates year, then energy produced in the following year may be denoted by $E_{n}(\mathrm{kWh})$. Therefore, on account of cell degradation, EGC of solar modules at any year $n$ can be modeled as:

$$
E_{n}=(1-0.008) E_{n-1}=(0.992) E_{n-1} ; \Rightarrow E_{n}=(0.992)^{n} E_{0}, \quad n=(1,2,3 \ldots)
$$

If 2015 is the base year of installation, then, $n=(1,2,3, ..) \equiv(2016,2017,2018, \ldots)$

Let Cumulative energy produced by the $n^{\text {th }}$ year, be denoted by $E_{c(n)}(\mathrm{kWh})$, hence,

$$
E_{c(n)}=E_{0}+E_{1}+E_{2}+\cdots+E_{n}=E_{0}\left(1+0.992+0.992^{2}+\cdots+0.992^{n}\right)
$$

Let the constant 0.992 be denoted by $k$ hence,

$$
E_{c(n)}=E_{0}\left(1+k+k^{2}+\cdots+k^{n}\right)=E_{0}\left(1+\sum k^{n}\right)=E_{0} k_{c(n)}
$$

where $k_{c(n)}$ is solar cell degradation factor [1] and $E_{0}=E_{a n n}$,

\subsection{Estimation of the Unit Cost of Solar Electricity}

Maintenance of solar installation and the accompanying accessories are negligible. Hence, if unit cost of energy produced by a PV in $n^{\text {th }}$ year is represented by $C_{P V(n)}(\mathrm{N} / \mathrm{kWh})$ and total cost of equipment by $C_{T}(\aleph)$, then, from first principles

$$
C_{P V(n)}=\frac{C_{T}}{E_{c(n)}}=\frac{C_{T}}{E_{0} k_{c(n)}}
$$

$\therefore$ Cost per unit of energy in the first year of installation $\left(k_{c(0)}=0.992\right)$ yields: $165.38 / \mathrm{KWh}$

\section{RESULTS AND DISCUSSION}

The result of implementing Equation (18) is shown in Table 4 followed by a graphical comparison of the two scenarios, presented in Figure 1. 
Table 4. Comparison of Solar PV-Grid Energy Cost Per Unit

\begin{tabular}{|c|c|c|c|c|c|c|c|c|}
\hline$S N$ & Year & $n$ & $C_{g(n)}, \mathbb{N}$ & $E_{0}, \mathrm{kWh}$ & $E_{n}, \mathrm{kWh}$ & $E_{c(n)}, \mathrm{kWh}$ & $C_{T}, \#$ & $C_{P V(n)}, \mathrm{NWh}$ \\
\hline 1 & 2000 & -15 & 2.60 & & & & & \\
\hline 2 & 2001 & -14 & 2.60 & & & & & \\
\hline 3 & 2002 & -13 & 4.00 & & & & & \\
\hline 4 & 2003 & -12 & 4.00 & & & & & \\
\hline 5 & 2004 & -11 & 4.00 & & & & & \\
\hline 6 & 2005 & -10 & 4.00 & & & & & \\
\hline 7 & 2006 & -9 & 4.00 & & & & & \\
\hline 8 & 2007 & -8 & 4.00 & & & & & \\
\hline 9 & 2008 & -7 & 4.00 & & & & & \\
\hline 10 & 2009 & -6 & 4.40 & & & & & \\
\hline 11 & 2010 & -5 & 5.90 & & & & & \\
\hline 12 & 2011 & -4 & 7.30 & & & & & \\
\hline 13 & 2012 & -3 & 11.69 & & & & & \\
\hline 14 & 2013 & -2 & 11.37 & & & & & \\
\hline 15 & 2014 & -1 & 14.82 & & & & & \\
\hline 16 & 2015 & 0 & 23.80 & $3,514.25$ & 3514.25 & 3514.25 & 645120 & 183.57 \\
\hline 17 & 2016 & 1 & 20.38 & & 3486.14 & 7000.39 & & 92.15 \\
\hline 18 & 2017 & 2 & 20.67 & & 3458.25 & 10458.63 & & 61.68 \\
\hline 19 & 2018 & 3 & 16.77 & & 3430.58 & 13889.21 & & 46.45 \\
\hline 20 & 2019 & 4 & & & 3403.14 & 17292.35 & & 37.31 \\
\hline 21 & 2020 & 5 & & & 3375.91 & 20668.26 & & 31.21 \\
\hline 22 & 2021 & 6 & & & 3348.90 & 24017.17 & & 26.86 \\
\hline 23 & 2022 & 7 & & & 3322.11 & 27339.28 & & 23.60 \\
\hline 24 & 2023 & 8 & & & 3295.54 & 30634.81 & & 21.06 \\
\hline 25 & 2024 & 9 & & & 3269.17 & 33903.99 & & 19.03 \\
\hline 26 & 2025 & 10 & & & 3243.02 & 37147.00 & & 17.37 \\
\hline
\end{tabular}

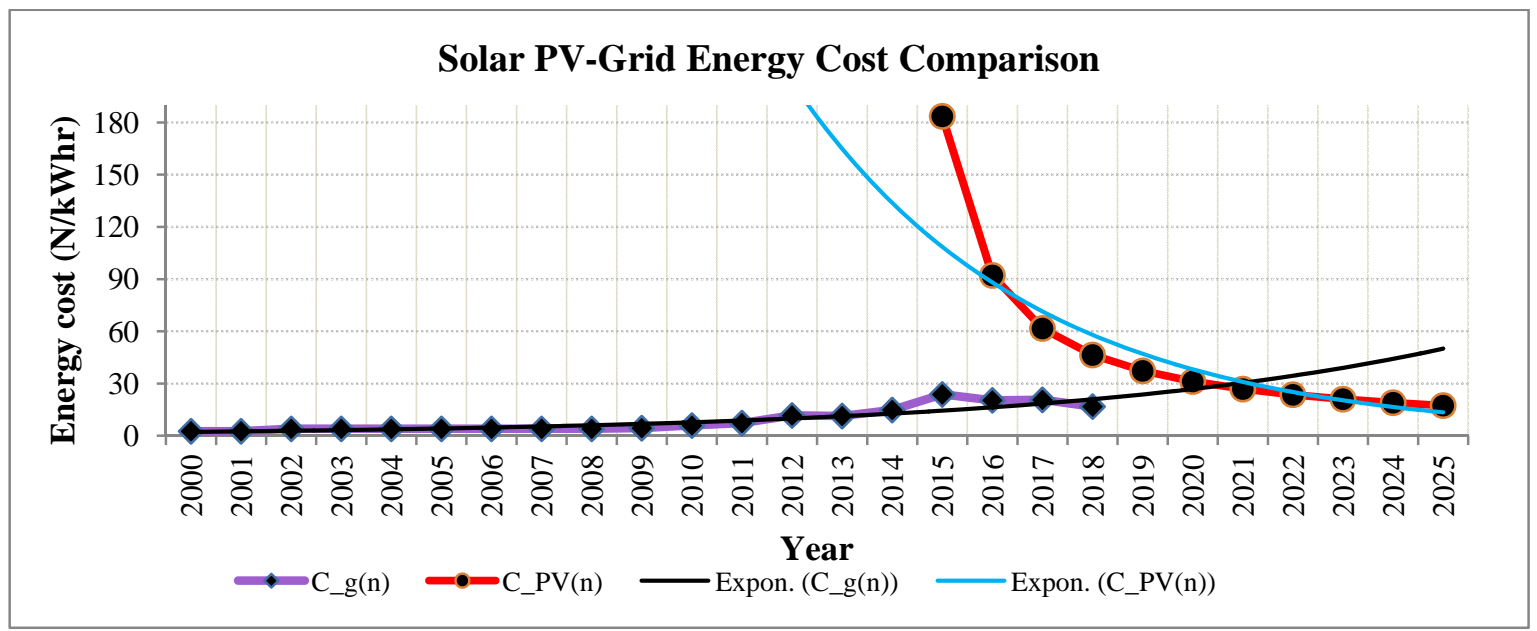

Figure 1. Comparative cost analysis of solar PV system and Grid supply

From Figure 1, it is observed that initial cost of energy from a solar PV system is very high but falls exponentially with the years since operation and maintenance cost is negligible. Trend line analysis of these graphs using Microsoft Excel chart wizard shows that the graphs may be described by:

$$
\begin{aligned}
& C_{P V(n)}=3083.5 e^{-0.209 n} \\
& C_{g(n)}=1.9627 e^{-0.1246 n}
\end{aligned}
$$

where $C_{P V(n)}$ and $C_{g(n)}$ are unit cost of solar electricity and grid supplied electricity in $n^{\text {th }}$ year. At the point of convergence (parity) of the two curves:

$$
C_{P V(n)}=C_{g(n)}=N 30.75 \text { per } k W h r ; \text { and } n=6^{\text {th }} \text { year }
$$


Reckoning from year 2015 inclusive, the $6^{\text {th }}$ year comes to the year 2021. This implies that a solar PV system installed in 2015 will be able to attain grid parity and subsequently, profitability above grid supply within 6 years after its installation. This is about $24 \%$ of the way into the 25 years average useful life of the installation

As suggested in [2], the following combination of factors is needed to speed up parity:

(a) Fall in the price of solar modules and inverters and reduction in the value of solar cell degradation factor are factors which will speed up grid parity.

(b) An energy production cost reflective tariff for utility grid supply

Table 5 reflects the trend of the above indices between 2011 and ending of 2014. As may beobserved, the suggested aids to early parity have played out resulting in the condition becoming achievable in the medium term as defined in [2]. Research and development efforts on solar modules to combat module defects that results in cell degradation such as module solder joint [12], $I_{s c}$ losses [13], corrosion and interconnect breakage [14] etc are in progress.

Table 5. Summary of Changes in Solar PV-Grid electricity Indices since 2011

\begin{tabular}{|c|c|c|c|c|}
\hline S/No & Indices & 2011 & 2014 & $\begin{array}{c}\% \\
\text { Change }\end{array}$ \\
\hline 1 & Utility energy Cost/Unit (NGN) & 7.3 & 14.82 & +103.01 \\
\hline 2 & Solar Module Price/Watt (\$) & 4.2 & 0.66 & -84.29 \\
\hline 3 & Inverter Price per watt (\$) & 0.715 & 0.27 & -62.80 \\
\hline 4 & Deep cycle battery Price/watt-hour (\$) & 0.207 & 0.09 & -56.39 \\
\hline 5 & Degradation Factor & 0.9929 & 0.992 & +0.09 \\
\hline 6 & Time of Parity (Years) & 14.3 & 6 & -58.04 \\
\hline 7 & Time of Parity as percentage of System's average useful life of 25years & 57.2 & 24 & -57.90 \\
\hline
\end{tabular}

As more success is recorded in research and development activities resulting in efficient and less degradable modules, more power per module square meter will be made available and useful lifespan will be elongated. Also, with increased interest in solar energy deployment, competition among manufacturers of modules, inverters, batteries and other accessories will be engendered resulting in considerableprice reduction.

The on-going deregulation of the Nigerian power sector is expected to result in improved power generation and cost reflective tariffs over time. These combinations of factors, when fully in place, are expected to aid earlier achievement of parity.

\section{CONCLUSION}

From the above analyses, it can be observed that the following factors have significantly affected the approach of solar energy to grid parity in terms of unit cost in the study location:

(i) Rapidly falling price/watt of solar modules, inverters and other accessories

(ii) Upward review of electricity tariff in Nigeria

The review showed that parity can now be achieved in the medium term (5-6 years) in typical Nigerian residences instead of the long term earlier predicted by [2] due majorly to improvement in energy tariff and drop in costs of solar power accessories. Sustained improved pricing of energy from the Distribution Service Providers (DSP) will further hasten parity. Also, further breakthrough in research and development efforts in the area of solar module energy conversion efficiency, weather resistance and nondegradable solar cell products are other factors needed to achieve early parity. Finally, with increased improvement and competitiveness in the inverter and deep cycle battery market, parity may even be achieved within the next three years. The implication of this scenario is that deployment of solar energy as on-grid or stand-alone Distributed Generation will become economically more feasible [19]. This will improve power availability for domestic, commercial and industrial applications.

\section{REFERENCES}

[1] M. Sadhu, S. Chakraborty, N. Das, P.K. Sadhu. Role of Solar Power in Sustainable Development of India..TELKOMNIKA Indonesian Journal of Electrical Engineering. 2015; 14(1): 34-41.

[2] A.O. Melodi and S.R. Famakin, Assessment of Solar PV-Grid Parity in Akure, South-West Nigeria. Journal of Emerging Trends in Engineering and Applied Sciences, pp. 531-536, 2011. 
[3] Solarbuzz, Solar Module Retail price Environment, Retrieved July 11, 2010, from Solarbuzz: http//www.solarbuzz.com, 2011.

[4] D. Feldman, R. Margolis and D. Boff, Q2/Q3 '14 Solar Industry Update Retrieved January 20, 2015, from energy. gov: http://www.Energy.gov/sunshot, 2014.

[5] NERC, Multi year tariff Order for the Determination of Charges and tariffs for Electricity Generation, Transmission and Retail Tariffs Retrieved July 6, 2010, from nercng: http://www.nercng.org, 2008.

[6] NERC, Multi year tariff Order (MYTO 2) for the Determination of Charges and tariffs for Electricity Generation, Transmission and Retail Tariffs Retrieved January 16, 2015, from nercng: http://www.nercng.org, 2012.

[7] NERC, Multi year tariff Order (MYTO 2.1) for the Determination of Charges and tariffs for Electricity Generation, Transmission and Retail Tariffs Retrieved January 16, 2015 from nercng: http://www.nercng.org,2015.

[8] C.R. Osterwald,A. Anderberg, S. Rummel, and L. Ottoson, Degradation analysis of Weathered Crystalline Silicon PV Modules. 29th IEEE PV Specialists Conference, New Orleans, Louisiana: National Renewable Energy Laboratories, pp. 1-7. 2002.

[9] S.R. Kurtz, and D.C. Jordan, Photovoltaic Degradation Rates: An Analytical Review. Retrieved January 17, 2015, from SciTech Connect: http://www.osti.gov/br, 2012.

[10] Sunsteams, Sun steams-Inverter Specification. Retrieved May 6, 2011, from pvsolarchina: http://www.pvsolarchina.com, 2011.

[11] R. Bhandari and I. Stadler, Grid Parity Analysis of Solar Photovoltaic Systems in Germany using Experience Curves, Renewable Energy, pp1634-1644, 2009.

[12] D.L. Quintana, M.A. Kratochvil, J.A., Ellibee and D.E. Hansen, Photovoltaic module performance and durability following long-term field exposure. Progress in Photovoltaics: Research and Application; pp 241-256, 2000.

[13] Y. Hishikawa, K. Morita, S. Sakamoto and T. Oshiro, Field test results on the stability of 2400 photovoltaic modules manufactured in 1990s. Proceedings of the 29th PV Specialists Conference, New Orleans, LA, USA, pp 1687-1690, 2002

[14] J.H. Wohlgemuth, D.W. Cunningham, A.M. Nguyen and J. Miller, Long-term Reliability of PV Modules. Proceedings of the 20th European PV Solar Energy Conference, Barcelona, Spain, pp. 1942-1948, 2005.

[15] Reeves, E.A. (1987). Newnes Electrical Pocket Book. London: William Heinemann Ltd.

[16] Reeves, E.A., \& Heathcote, M. (2013). Newnes Electrical Pocket Book. Taylor \& Francis.

[17] Ebay, Home and Garden. Retrieved January 2015, from Ebay: www.ebay.com

[18] Central Bank of Nigeria. CBN Exchange Rates. Retrieved January 2015, from Central Bank of Nigeria: www.cenbank.org.

[19] A. Kadam, K. Unni, S. Thale, Performance Analysis of Voltage Stability against Sudden Load Changes in Voltage Controlled Inverters for Distributed Generation. International Journal of Applied Power Engineering, pp. 33-40, 2014

\section{BIOGRAPHIES OF AUTHORS}

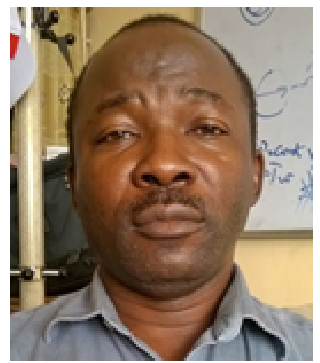

Melodi, Adegoke Oladipo is an Associate Professor of Electrical Engineering in the Department of Electrical and Electronics Engineering, Federal University of Technology, Akure, Nigeria. He obtained a Ph.D. degree in Moscow in 2005. He has attended and published papers at local and international engineering conferences and also published in peer-reviewed journals. He has successfully supervised many students' theses at Master degree level in power and renewable energy systems engineering, and currently training some students towards obtaining the Ph.D. degree in power systems engineering.

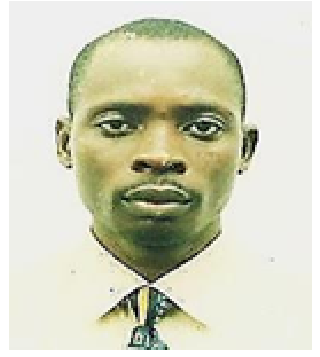

Famakin Sola Richards is a lecturer in the Department of Electrical and Electronics Engineering of the Federal university of Technology, Akure, Nigeria. He obtained a Masters Degree in Electrical Engineering in 2011 from the Federal University of Technology, Akure, Nigeria. He has published papers in peer-reviewed journals and is currently working on his Ph.D. degree. 